Litteratur

1. Berstad TL. Helseutgiftene i Norge er ikke spesielt høye. Tidsskr Nor Legeforen 2013; 133: 503

2. Melberg HA. Bruker Norge mye eller lite til helseformål sammenlignet med andre land? Perspektiv 03/12. Oslo: Stortingets utredningsseksjon, 2012 www.stortinget.no/Global/pdf/Utredning/Perspektiv \%2003-12.pdf (15.4.2013).

Dette er en redigert versjon av et innlegg publisert som rask respons på nett 11.3.2013 http://tidsskriftet.no/article/2979106/

\section{Unødvendig forvirring om helseutgifter}

Terje L. Berstad har i Tidsskriftet nr. 5/2013 noen kommentarer til en rapport jeg har skrevet til Stortinget om helseutgiftene i Norge (1). Hovedbudskapet i rapporten er ikke at vi bruker lite eller mye på helse, men at svaret avhenger av hva man sammenlikner: Norge ligger høyt i forhold til andre land når vi sammenlikner rene dollarutgifter. Vi ligger mer midt på treet når man justerer for både det generelle prisnivået og helsespesifikke priser, og vi ligger lavere i forhold til vår inntekt.

Dette er fremstilt i illustrasjonen nedenfor, som viser helseutgiftene i Norge og 19 andre land i OECD. Utgiftene til eldreomsorg er tatt ut fordi mange land regner dette som en sosialutgift, mens andre fører det som en helseutgift. Slik unngås regnskapsmessige problemer, men man mister også det aspekt at Norge bruker mer på denne delen av heletjenesten enn mange andre land.

Illustrasjonen viser at vi bruker betydelig mer enn gjennomsnittet målt i dollar. Vi har imidlertid også høye priser og lønninger. Tar man hensyn til hvor mye man får per krone, blir forskjellen mellom Norge og andre land mindre. Det har mindre betydning i denne sammenlikningen om man bruker det generelle prisnivået i Norge eller Eurostats indeks for helsepriser. Begrepsmessig er helsespesifikke priser det mest relevante, men OECD og andre har hittil valgt å bruke det generelle prisnivået fordi man har vært bekymret for kvaliteten på helseprisindeksen. Målt som andel av inntekten, bruker vi mindre på helsetjenester enn andre land. Man kunne gå videre og argumentere at heller ikke dette er dekkende fordi inntektene tar med salg av naturressurser som olje og gass. Hvis man tar bort oljeinntektene, er andelen av våre inntekter som brukes på helse, høyere enn gjennomsnittet. Hvilke tall som er mest relevante, vil avhenge av formålet med analysen.

Debatten om helseutgifter burde ikke være så vanskelig. Tallene brukes ofte til politiske formål. Den politiske interessen i å opprettholde ulike konklusjoner («vi bruker mye» mot «vi bruker lite»)

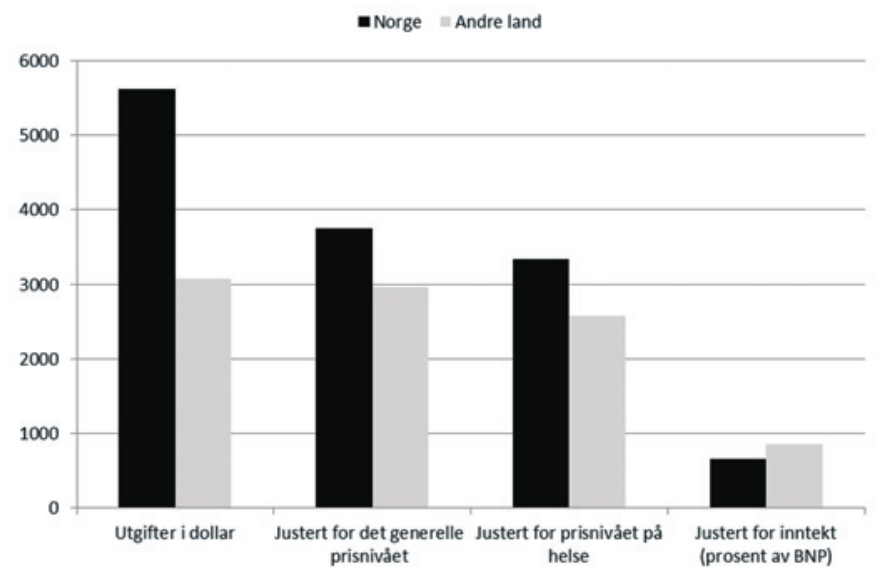

Helseutgiftene i Norge og 19 andre OECD-land i 2011. Søylene for helseutgiftene som prosent av bruttonasjonalprodukt er på skala der $100 \%$ er 10000 . Utvalget består av de landene som i 2011 hadde tilgjengelige tall for utgifter, priser og andre variable som inngikk i utregningene, inkludert USA der dette var mulig. Forfatter har laget illustrasjonen basert på tall fra OECD Health Data og Eurostat. Utvalget består av de landene som 2011 hadde tilgjengelige tall for utgifter, priser og andre variabler som inngikk i utregningene (2) sementerer unødvendig forvirring. Sannheten er at vi bruker mer enn de fleste målt i dollar, mer gjennomsnittlig i forhold til prisnivået, og mindre enn gjennomsnittet når man ser på helseutgiftene i forhold til inntekten.

\section{Hans Olav Melberg \\ hans.melberg@gmail.com}

Hans Olav Melberg (f.1970) er førsteamanuensis i helseøkonomi ved Universitetet i Oslo og for tiden Harkness Fellow ved University of Pennsylvania, USA.

Ingen oppgitte interessekonflikter.

\section{Litteratur}

1. Berstad TL. Helseutgiftene i Norge er ikke spesielt høye. Tidsskr Nor Legeforen 2013; 133: 503

2. Helsenyheter - smått og stort om helse og økonomi. http://helsenyheter.blogspot.no/ (15.4.2013)

Dette er en redigert versjon av et innlegg publisert som rask respons på nett 18.3.2013 http://tidsskriftet.no/article/2979106/

\section{Terje L. Berstad svarer:}

Toril F. Bergsjø i Stortingets utredningsseksjon oppgir at artikkelen er misvisende. Men i notatet konkluderer Hans Olav Melberg klart og tydelig at vi har høye helseutgifter: «Noe av grunnen til at Norge har høye utgifter er at vi har høy lønn i forhold til andre, men noe skyldes også at vi ikke er så effektive som enkelte andre land» (1). Det Bergsjø henviser til, likner mer på en metodebeskrivelse enn en konklusjon. Melbergs påstand om at det har mindre betydning om man bruker det generelle prisnivået i Norge eller Eurostats indeks for helsepriser er feil. Forskjellen mellom generelt prisnivå og prisnivå for helsetjenester i 2011 er 18,2 \% hos Eurostat. Det har stor betydning. Forskjellen i 2009 betyr ca. 16 milliarder, og det dekker mange behandlinger. Melberg kan ha brukt OECDs paritet for 2008. Der er USA basislandet. Melberg har selv påvist høyt lønnsnivå innen helse i USA i sine tidligere arbeider. Pariteten er dermed ikke egnet.

Jeg antar vi er enig om at Norge, som er et rikt land, kjøper usedvanlig lite helsetjenester. Helseutgiftene er ikke større enn det, uansett om vi måler det i dollar eller som «alternativ kostnad». Vi har et høyt kostnadsnivå, men dette er båret frem av en norsk tradisjon om å fordele rikdommen. Vi har fordelt landets inntekter slik at gjennomsnittslønnen er høy sammenliknet med andre land. Antakelig har vi gjort dette i større grad enn noen annen sivilisasjon. Dette er noe vi skal være stolt av. Kravet har altså ikke vært økt produktivitet for høyere lønn.

Terje L. Berstad

terjelb@hotmail.com

Terje L. Berstad (f. 1969) er cand.polit. i medievitenskap og arbeider som analytiker i firmaet Public Mode. Han har tidligere arbeidet i Helsedirektoratets statistikkavdeling.

Ingen oppgitte interessekonflikter.

\section{Litteratur}

1. Melberg HA. Bruker Norge mye eller lite til helseformål sammenlignet med andre land? Perspektiv 03/12. Oslo: Stortingets utredningsseksjon, 2012: 9. www.stortinget.no/Global/pdf/Utredning/Perspektiv\%2003-12.pdf (15.4.2013).

Dette er en redigert versjon av et innlegg publisert som rask respons på nett 19.3. 2013 http://tidsskriftet.no/article/2979106/ 